\title{
ЕДНО НОВО ИЗСЛЕДВАНЕ ВЪРХУ СЪВРЕМЕННАТА БЪЛГАРСКА РЕЧ
}

\author{
BILYANA TODOROVA \\ South-West University "Neofit Rilski" in Blagoevgrad
}

\begin{abstract}
A NEW RESEARCH ON CONTEMPORARY BULGARIAN SPEECH. A review of: Stalyanova, Nadezhda. Speech in Modern Bulgarian Society. Sofia: Paradigma, 2020, 154 Pp. ISBN 978-954-326413-1 [In Bulgarian: Сталянова, Надежда. Речта в съвременното българско общество. София: Парадигма, 2020, 154 с.].
\end{abstract}

Keywords: Nadezhda Stalyanova, speech, Bulgarian language, verbal aggression, political speech

Още заглавието на излязлата през 2020 година книга на Надежда Сталянова Речта в съвременното българско общество разкрива амбицията на авторката да представи актуалните процеси, свързани с развитието на българския език. Фокусирането върху речта, върху конкретните езикови проявления, с които се сблъскваме ежедневно, често обсъждаме, критикуваме, но и които следваме, понякога несъзнателно, е интересна, навременна и трудна задача заради противоречивите оценки по отношение на процесите, наблюдавани в публичната реч. Именно на връзката между езика и обществото изследователката посвещава своето внимание, като разглежда влиянието на обществените процеси върху езиковите явления.

Книгата представя работата на Надежда Сталянова в рамките на проекта Езикова агресия и общество, финансиран от Фонд Научни изследвания към МОН. Ето защо първата част от изданието представя обобщения резултат от анкети на средношколци, проведени в периода 2016-2019 година, които изследват измеренията на вербалната агресия в днешното общество. Резултатите показват, че словесната агресия е част от ежедневието на съвременните ученици, като те се срещат с нея найвече в интернет, но също така и на улицата, в училището, в транспортните средства и пр. Въпреки че в голямата си част гимназистите признават, че използват агресивна лексика, те демонстрират завидна устойчивост спрямо обидите и агресивните послания, като 40\% от анкетираните заявяват, че чуждото вербално поведение не е в състояние да ги засегне и нарани. Най-чувствителни анкетираните млади хора са към 
обиди, свързани с интелектуалните способности, външния вид, поведението, в много по-малка степен реагират на езикови употреби, свързани със сексуалната ориентация или с етническа / расова дискриминация.

Въпреки че толерантността е смятана за един от фундаментите на съвременната демокрация, в последните години наблюдаваме засилване на проявите на вербална агресия в общественото пространство, както и на поляризацията на публичния дискурс. Както Н. Сталянова посочва, вербалната агресия е типична за тийнейджъpume (с. 42), но колкото по-агресивно и нетолерантно е едно общество, толкова побезкритично се възприемат подобни прояви и от страна на младите хора. Ето защо ми се струва, че възпитанието в толерантност и чувствителността към емоциите на другите не може и не бива да остават само в учебните програми.

Втората част от книгата е озаглавена Нови думи и значения и представя разширяването на значенията на вече съществуващи думи в българския език, като проект, експертиза, дребнотемие, политик. Освен че при някои от тези думи се разширява и променя основното значение, отбелязано в речниците, в голяма част от случаите тези значения носят и нова, положителна или отрицателна стилистична окраска.

Третата част на книгата е посветена на много актуалната в световната лингвистика тема за политическата коректност и джендър неутралната лексика. Както е известно, прилагането към славянските езици на модели, характерни за език като английския, в който липсва категорията род при съществителните имена, е нелека задача. В ежедневната си практика обаче филолозите се сблъскват с допълнителни въпроси, свързани с употребата на термини, преносни употреби и идиоматични конструкции, съдържащи съставки, които биха могли да бъдат определени като обидни и отразяващи стереотипни представи - например думи и фрази като осиновявам, синовен дълг, дъщерна фирма, инвалидна количка и пр. Въпреки че не съдържат негативна конотация, вероятно под влияние на световните тенденции тези употреби постепенно ще бъдат ограничавани и променяни. Дали обаче външният натиск за промени в езика, които не отразяват обществените настроения, няма да срещне отпор от страна на средностатистическия носител на българския език, предстои да видим.

Важна част от книгата представляват текстовете, посветени на политическата реч, като особено интересен поне за мене е акцентът върху употребата на клиширани думи и фрази, използвани в слоганите на предизборните билбордове и плакати. Оказва се, че стремежът към кратко и запомнящо се послание води до използването на идентични конструкции от страна на множество участници в предизборната надпревара. По тази причина Н. Сталянова прави обобщението, че обликът на 
кандидатите се размива, обещанията и програмите губят или не постигат отчетливост, а политиците са неразпознаваеми по отношение на словото си (с. 95).

Последната част на книгата представя някои промени във фразеологията в последните години. Оказва се, че част от добре известни на предишните поколения устойчиви словосъчетания са непознати за младите хора днес; други се използват не в значението, описано в речниците; трети може да изчезнат, ако политически коректният език стане норма в публичното говорене. И фразеологизмите, както останалите лексикални единици, не остават незасегнати от промените в обществото.

Представените от авторката проявления на съвременната речева ситуация разкриват нещо важно - лексикалната система е динамична, езиковото поведение на всеки от нас е от значение, то влияе, променя, възпитава. Ето защо е важно да подхождаме към речта си с отговорност, грижа и обич към българския език. 